\title{
Evaluating Couple Simple Shear Wall as Low-cost Masonry Wall Strengthening by Rebound Hammer Test
}

\author{
Rr. M. I. Retno Susilorini' ${ }^{1 *}$, Rina Febrina ${ }^{2}$, Helmia Adita Fitra ${ }^{3}$ \\ ${ }^{I}$ Department of Infrastructure and Environmental Engineering, Faculty of Environmental Science and Technology, \\ Soegijapranata Catholic University, Jl. Pawiyatan Luhur IV/1, Bendan Dhuwur, Semarang 50234, Indonesia \\ ${ }^{2}$ Department of Civil Engineering, Faculty of Engineering, Malahayati University, Lampung, Indonesia \\ ${ }^{3}$ Department of Regional Planning, Faculty of Infrastructure Planning, Sumatera Institute of Technology, Lampung, Indonesia
}

*Corresponding author: ORCID 0000-0001-8531-7485

\begin{abstract}
Shear wall known as high performance structure to resists seismic load. It has important that shear wall can be applied to masonry building as bearing wall in simple way, high performance, and low-cost. Therefore, this research wants to develop a simple way as well as simple shear walls that are connected by column as stiffer couple to strength the masonry wall. The aim of this research is to investigate compressive strength of couple simple shear wall compared to analytical compressive strength and also compressive strength of previous research. There were two couples of simple shear wall built on site, one was strengthening of the outer side of house wall and the other one was strengthening of the inner of masonry wall border edging, which are connected with column that placed at the edge and also in the corner. Each wall has dimension of $1 \times 1 \times 0.2 \mathrm{~m}$ while the column dimension was $0.20 \times 0.20 \mathrm{~m}$. Field application in this research followed by Rebound Hammer Test. The field result then compared of theoretical compressive strength and compressive strength of previous research. It is proven that couple simple shear wall easy to build and low-cost as well as simple design, ease for construction, and effectively strengthens the wall. The couple simple shear wall compressive strength was higher compared to compressive strength of masonry walls without strengthening and the theoretical compressive strength.
\end{abstract}

Keywords: couple, simple, shear wall, masonry wall, strengthening, Rebound Hammer, low-cost.

\section{INTRODUCTION}

Masonry building is low-cost structure that built in urban housing in many countries. The wall of masonry building generally unreinforced and designed to become a bearing wall. Since many cities in the world are prone area to earthquake, it is important to strengthen the masonry wall to reduce potential failure and collapse of the masonry building.
Several studies have reported about the importance of strengthening the masonry wall [1-7], even [8] developed strengthening methods for old historical masonry building in Slovenia, but there is little information about simple way to strengthening the masonry wall effectively, highly performance, and low-cost.

Shear wall is a structure that aims to resist lateral load such as seismic and wind loads [9-12]. For common masonry building, shear wall can be built as bearing wall. Indonesia National Standard of SNI 03-2847-2013 The Requirement of Structural Reinforced Concrete for Building Structure requires the thickness of shear wall should not be less than $10 \mathrm{~mm}$ to assure its performance to resist seismic load. Hence, this research wants to develop a simple way as well as simple shear walls that are connected by column as stiffer couple to strength the masonry wall, especially the unreinforced masonry wall. The couple simple shear wall in this research is investigated for its compressive strength compared to analytical compressive strength and also compressive strength of previous research[13].

\section{MATERIALS AND METHODS}

\section{II.I. Materials}

Material used in this research is local product and low-cost, i.e. clay bricks, wire mesh, steel reinforcement, cement, and sand. Design of the couple simple shear wall was described by Fig 1 and Fig 2. Couple simple shear wall purposed to become stiffer of the masonry wall, especially unreinforced masonry wall. There were two couples of simple shear wall built on site, one was strengthening of the outer side of house wall and the other one was strengthening of the inner of masonry wall border edging. The wall dimension was $1 \times 1 \times 0.2 \mathrm{~m}$ while the column dimension was of $0.20 \times 0.20 \mathrm{~m}$ as explained by Table 1. Two walls of the couple simple shear wall connected with column that placed at the edge and also in the corner (Fig 1). 


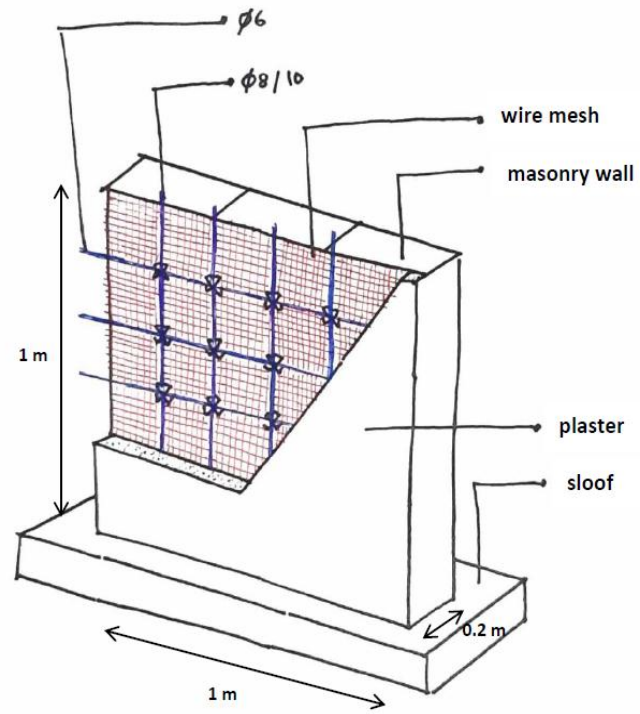

DETAIL OF SIMPLE SHEAR WALL ASSEMBLY AXONOMETRIC SCALE 1:10

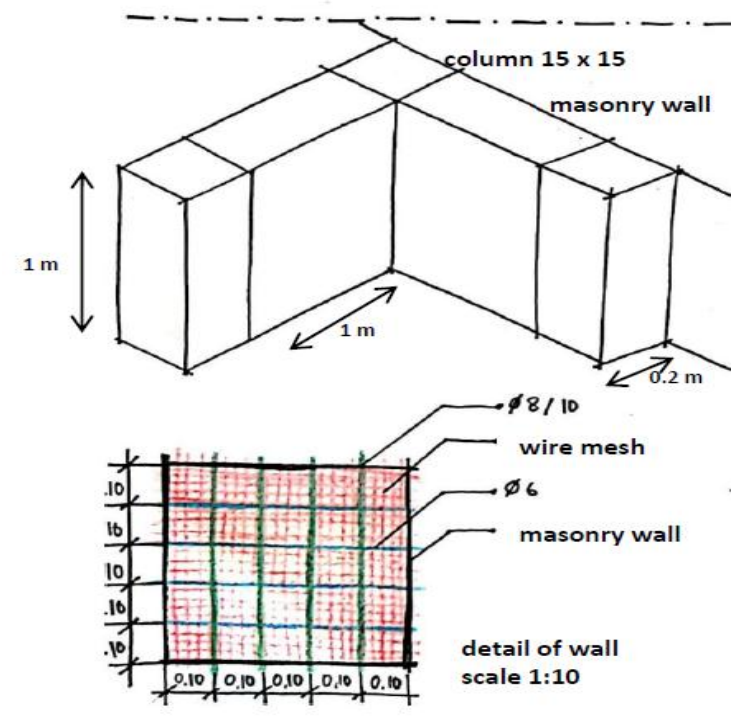

AXONOMETRIC SIMPLE SHEAR WALL SECTION SCALE 1:10

Fig 2. Design of Simple Shear Wall

Fig 1. Detail of Simple Shear Wall

Table 1. Dimension and placement of the couple simple shear wall

\begin{tabular}{|c|c|c|c|c|}
\hline \multirow{2}{*}{$\begin{array}{l}\text { specimen } \\
\text { code }\end{array}$} & \multicolumn{3}{|c|}{$\begin{array}{l}\text { dimension of the simple shear } \\
\text { wall }\end{array}$} & \multirow{2}{*}{ placement of the simple shear wall } \\
\hline & $\begin{array}{l}\text { length } \\
(\mathrm{mm})\end{array}$ & $\begin{array}{l}\text { height } \\
(\mathrm{mm})\end{array}$ & $\begin{array}{l}\text { width } \\
(\mathrm{mm})\end{array}$ & \\
\hline I-D-A & 100 & 100 & 20 & \multirow{10}{*}{$\begin{array}{l}\text { the inner of masonry wall border } \\
\text { edging }\end{array}$} \\
\hline I-D-B & 100 & 100 & 20 & \\
\hline $\mathrm{I}-\mathrm{D}-\mathrm{C}$ & 100 & 100 & 20 & \\
\hline I-D-D & 100 & 100 & 20 & \\
\hline I-D-E & 100 & 100 & 20 & \\
\hline II-D-A & 100 & 100 & 20 & \\
\hline II-D-B & 100 & 100 & 20 & \\
\hline II-D-C & 100 & 100 & 20 & \\
\hline II-D-D & 100 & 100 & 20 & \\
\hline II-D-E & 100 & 100 & 20 & \\
\hline III-L-A & 100 & 100 & 20 & \multirow{10}{*}{ the outer side of house wall } \\
\hline III-L-B & 100 & 100 & 20 & \\
\hline III-L-C & 100 & 100 & 20 & \\
\hline III-L-D & 100 & 100 & 20 & \\
\hline III-L-E & 100 & 100 & 20 & \\
\hline IV-L-A & 100 & 100 & 20 & \\
\hline IV-L-B & 100 & 100 & 20 & \\
\hline IV-L-C & 100 & 100 & 20 & \\
\hline IV-L-D & 100 & 100 & 20 & \\
\hline IV-L-E & 100 & 100 & 20 & \\
\hline
\end{tabular}




\section{II.II. Research Program}

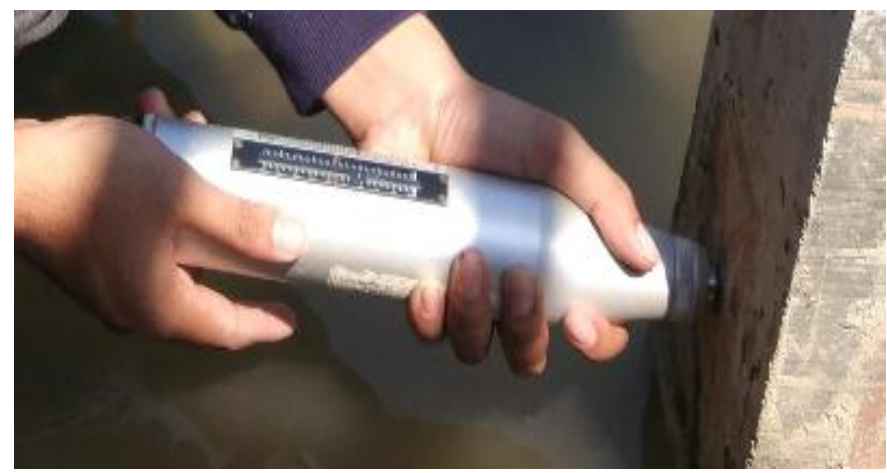

Fig 3. Rebound Hammer Test Equipment

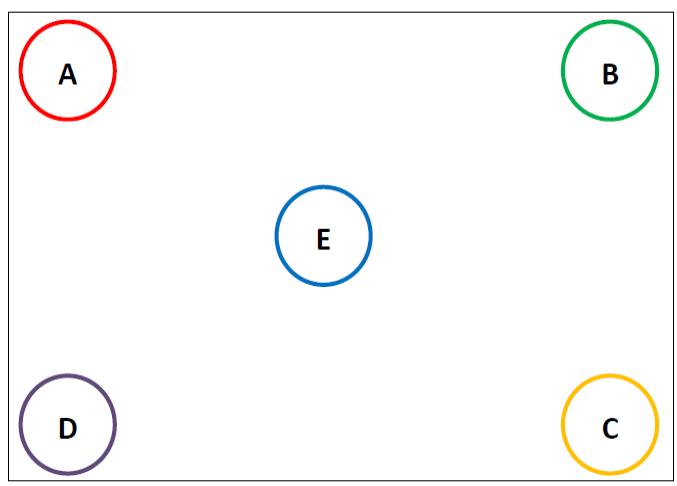

Fig 4. Rebound Hammer Test shooting points on the simple shear wall

The research was conducted firstly by construction of couple simple shear wall and followed by non-destructive test to investigate compressive strength of the wall from field application. Non-destructive test carried out by Rebound Hammer Test with equipment of Matest 2H1Q17 as described by Fig 3 and the shooting points described by Fig 4 . Analytical calculation then performed to get theoretical compressive strength. Instead of analytical calculation, research of [13] that reported average compressive strength of $40.30 \mathrm{MPa}$ of masonry wall without strengthening in the same site will be compared to this current investigation. It should be noted that applied natural polymers for the bricks as also investigated by [14]-[17].

Theoretical compressive strength be calculated by Equation (1) of [18].

$$
f_{c}^{\prime}=1.14 N_{R}-12.76
$$

Where:

$$
\begin{array}{ll}
f^{\prime}{ }_{c} & =\text { compressive strength }(\mathrm{MPa}) \\
N_{R} & =\text { Rebound Number }
\end{array}
$$

\section{II.II.1. Field Application}

Construction of couple simple shear-wall as field application is described by Fig 5 to Fig 8. Construction of the couple simple shear wall can be explained by procedure as follow.

1. Foundation construction

2. Sloof construction

3. Inner wire mesh installation

4. Column construction

5. Brick wall construction

6. Outer wire mesh installation

7. Outer reinforcement installation

8. Plastering and finishing work

Two couples of simple shear walls were successfully constructed because of the ease of construction and then being tested for Rebound Hammer Test after getting hardened.

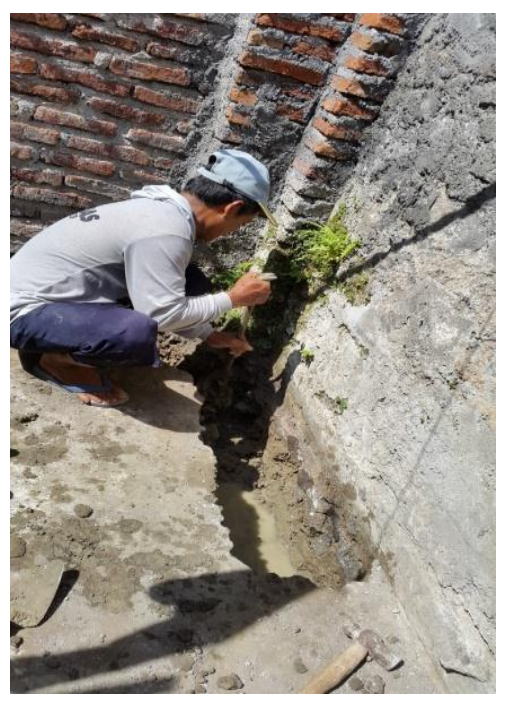

(a)

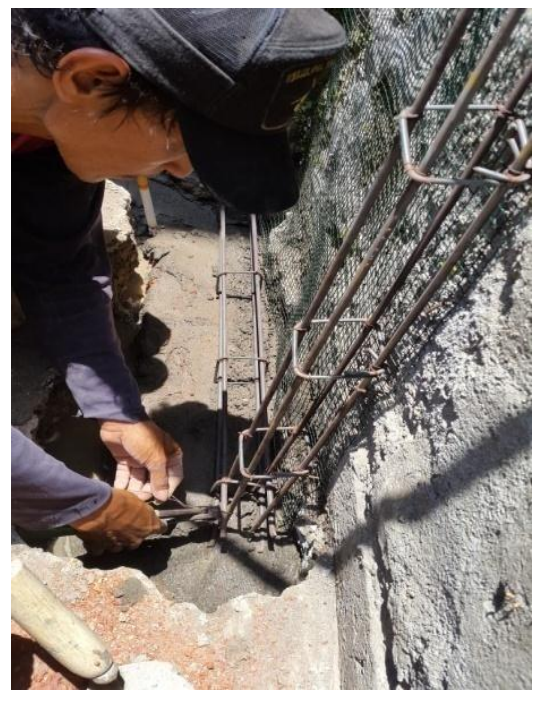

(b)

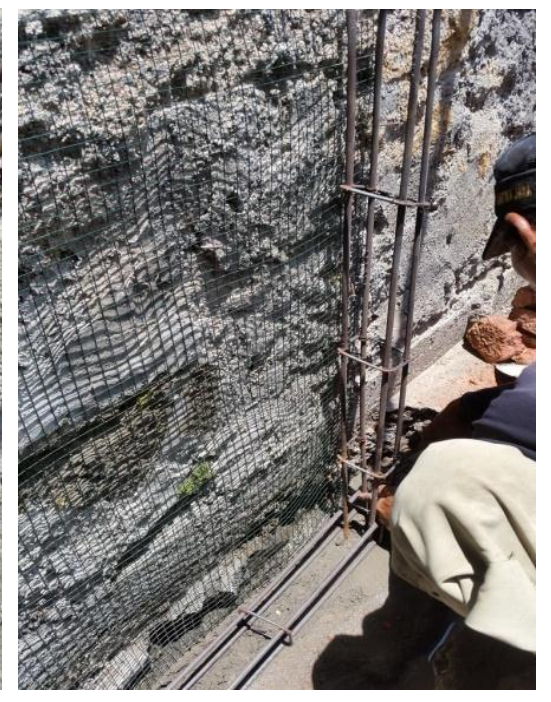

(c)

Fig 4. Initial stages of couple simple shear wall construction: (a) Foundation construction, (b) Column reinforcement, (c) Inner wire mesh installation 


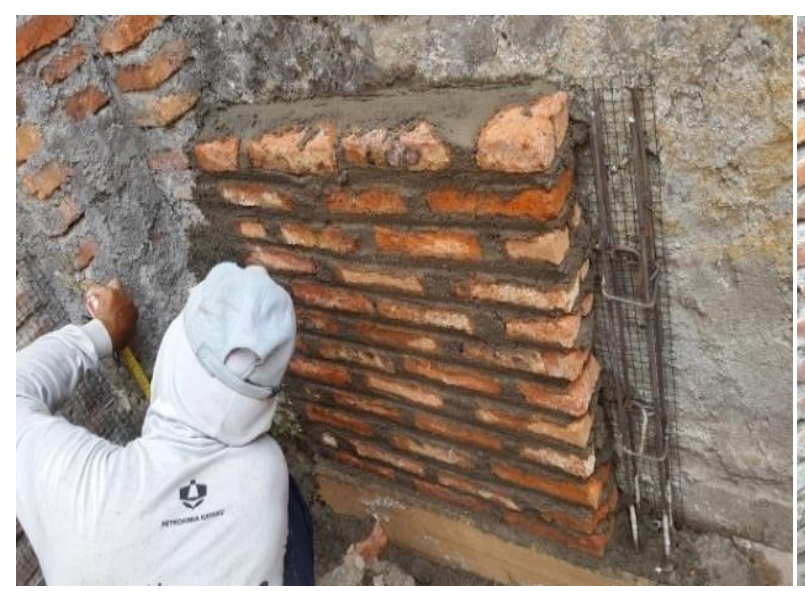

(a)

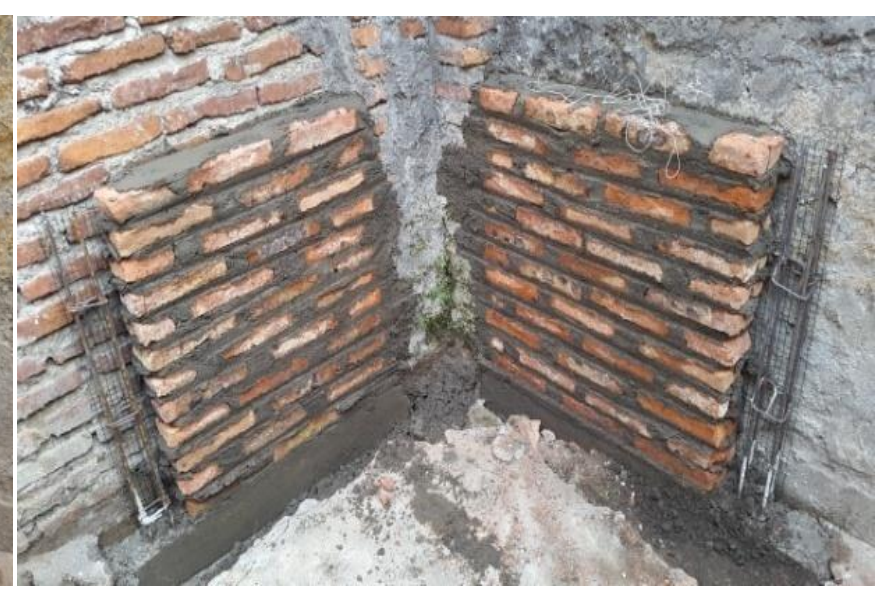

(b)

Fig 6. Brick wall construction: (a) One side of wall construction, (b) Two sides of wall construction

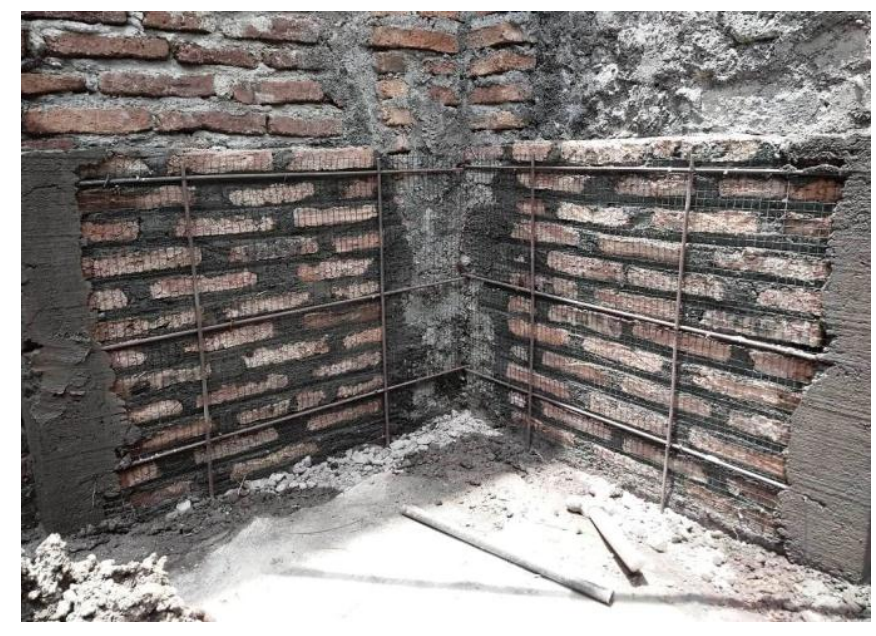

(a)

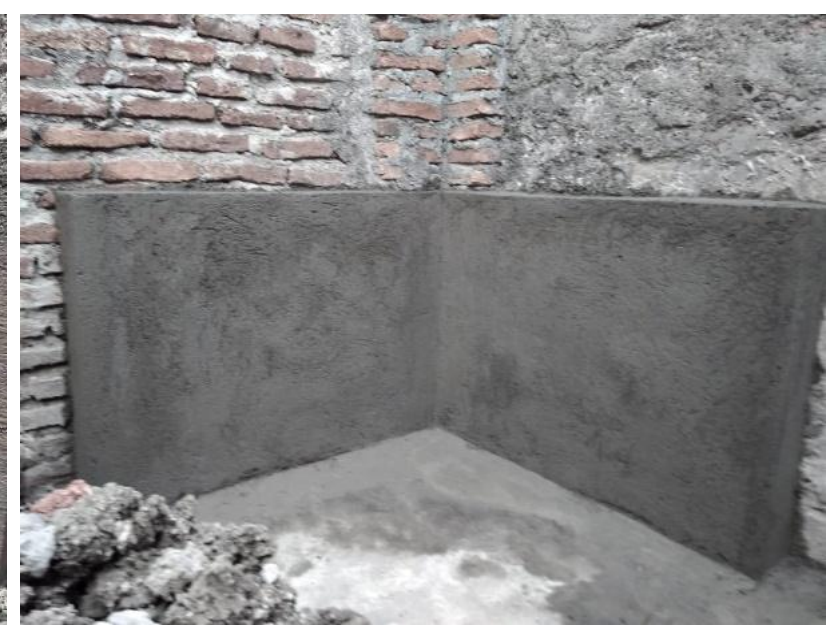

(b)

Fig 7. (a) Outer wire mesh and reinforcement installation, (b) Plastering work

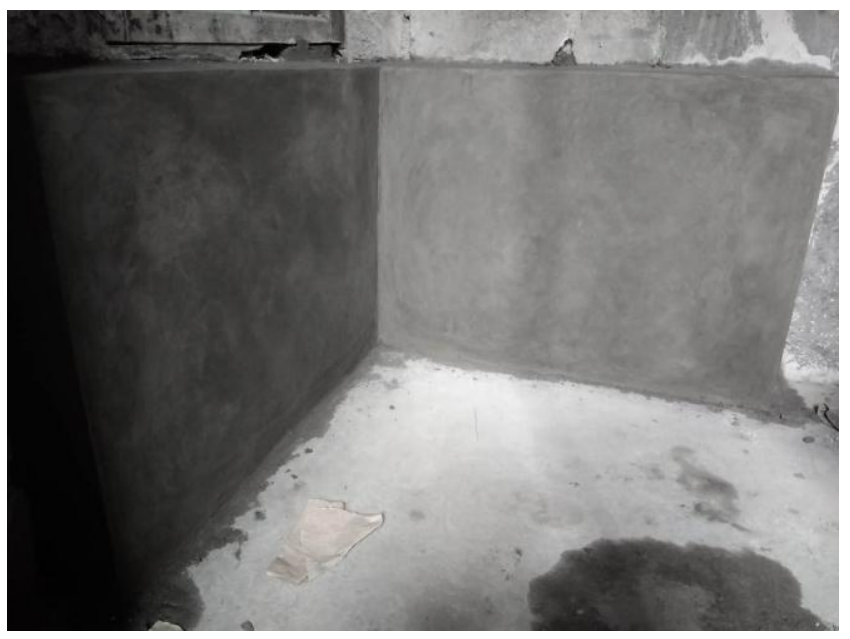

(a)

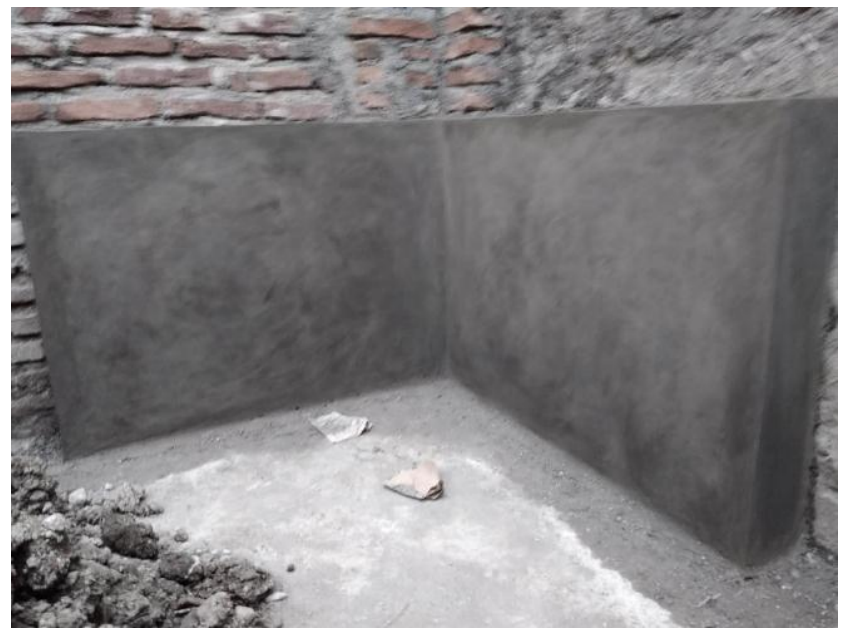

(b)

Fig 8. Finishing stage: (a) Couple simple masonry wall placed at the inner of masonry wall border edging (I-II series), (b) Couple simple masonry wall placed at the outer side of house wall (III-IV series) 
International Journal of Engineering Research and Technology. ISSN 0974-3154 Vol.13, No.3 (2020), pp. 600-607

(C) International Research Publication House. https://dx.doi.org/10.37624/IJERT/13.3.2020.600-607

\section{II.II.II. Rebound Hammer Test}

Rebound Hammer Test has been carried out to two couples of simple shear wall. Shooting points of the test placed as described by Fig 4. Each point had shot for 5 times as described by Table 2 .
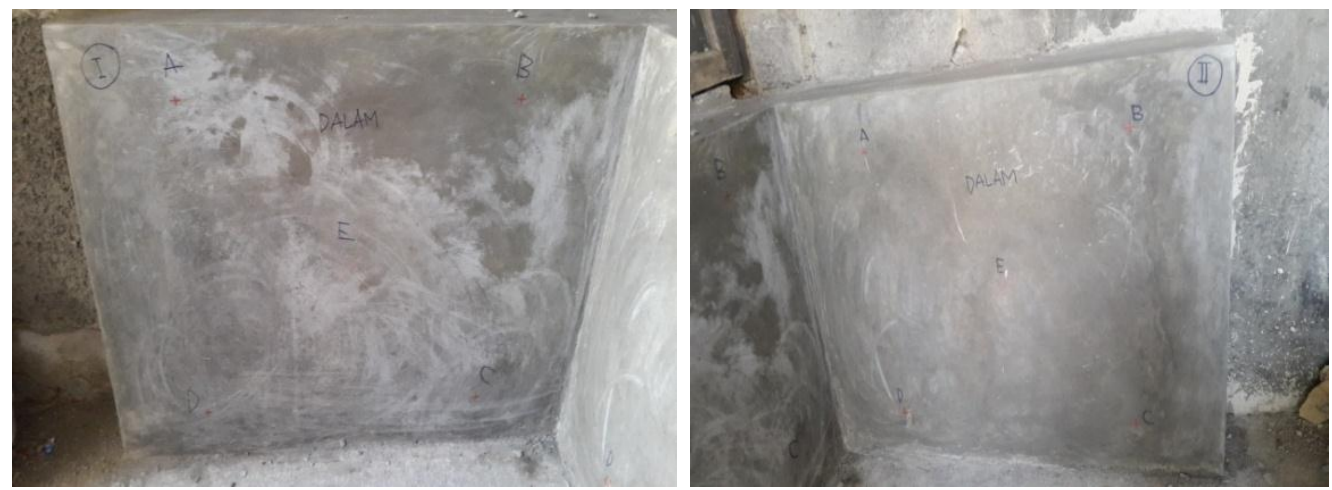

Fig 9. Marking of points of shooting at the surface couple of simple shear walls
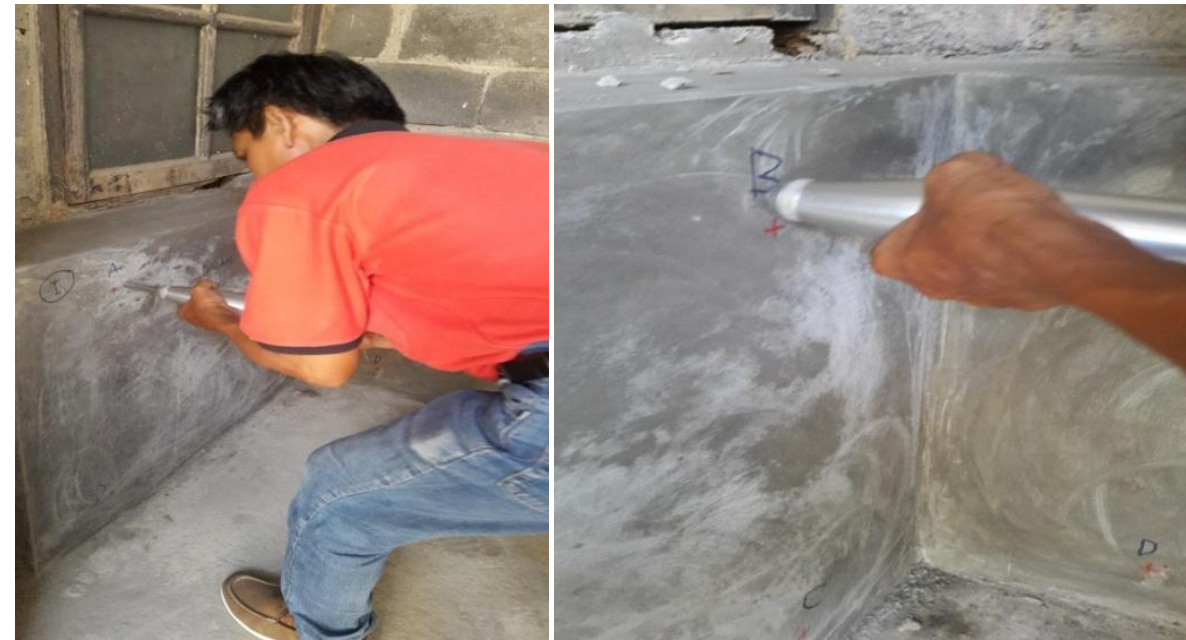

Fig 10. Shooting the points of simple masonry wall placed at the outer side of house wall (I-II series)
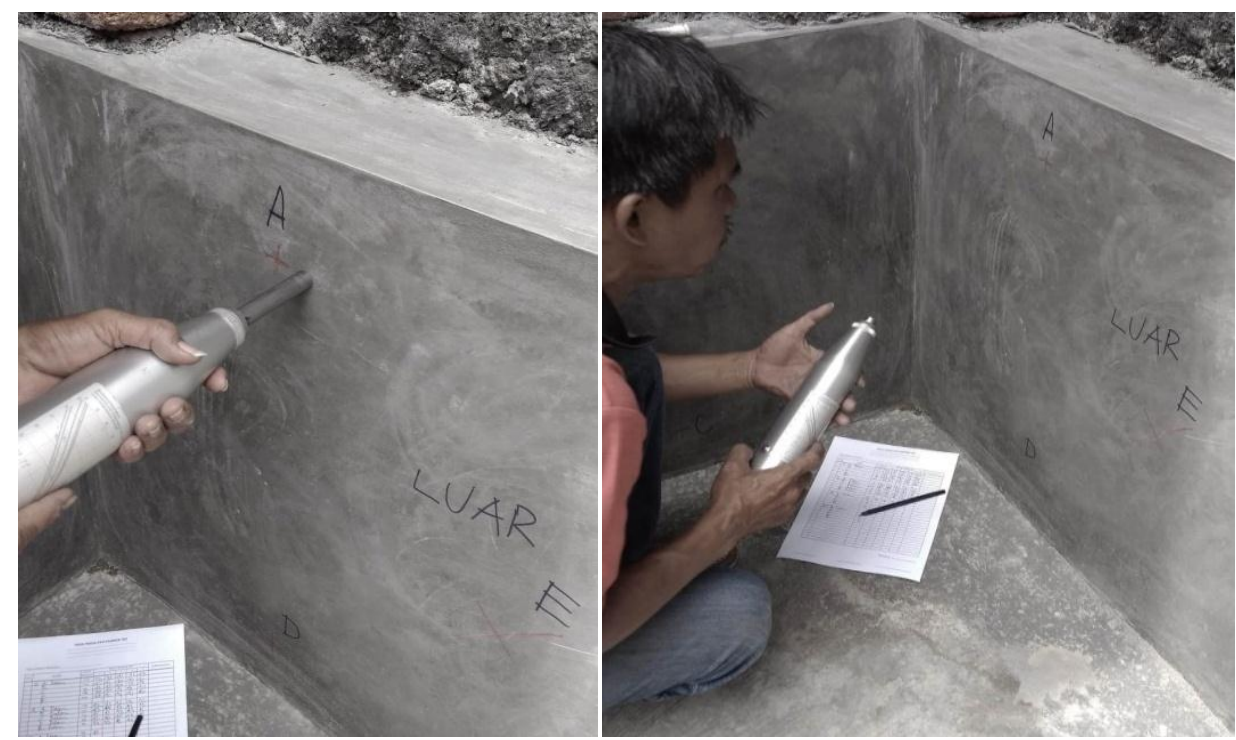

Fig 11. Shooting the points of simple masonry wall placed at the inner of masonry wall border edging (III-IV series) 
International Journal of Engineering Research and Technology. ISSN 0974-3154 Vol.13, No.3 (2020), pp. 600-607

(C) International Research Publication House. https://dx.doi.org/10.37624/IJERT/13.3.2020.600-607

\section{RESULT AND DISCUSSION}

Table 2. Compressive Strength Analysis of Rebound Hammer Test

\begin{tabular}{|c|c|c|c|c|c|c|c|c|c|c|c|c|}
\hline \multirow{2}{*}{$\begin{array}{l}\text { specimen } \\
\text { code }\end{array}$} & \multicolumn{5}{|c|}{$\begin{array}{l}\text { Observed Rebound Number } \\
\qquad\left(\mathrm{N}_{\mathrm{R}}\right)\end{array}$} & \multirow{2}{*}{$\mathrm{R}_{\text {average }}$} & \multirow{2}{*}{$\begin{array}{c}\text { Revised } \\
\text { R }\end{array}$} & \multirow{2}{*}{$\mathrm{W}_{\max }$} & \multirow{2}{*}{$\mathrm{W}_{\min }$} & \multirow{2}{*}{$\mathrm{W}_{\text {average }}$} & \multirow{2}{*}{$\begin{array}{c}\mathrm{f}^{\prime}{ }_{\mathrm{c}} \\
(\mathrm{MPa})\end{array}$} & \multirow{2}{*}{$\begin{array}{c}\mathrm{f}_{\mathrm{c}}^{\prime} \\
\text { average } \\
(\mathrm{MPa})\end{array}$} \\
\hline & 1 & 2 & 3 & 4 & 5 & & & & & & & \\
\hline I-D-A & 42 & 42 & 41 & 41 & 43 & 41.8 & 41.8 & 440.68 & 377.92 & 409.30 & 41.72 & \multirow[b]{5}{*}{39.54} \\
\hline I-D-B & 40 & 41 & 40 & 40 & 41 & 40.4 & 40.4 & 416.04 & 354.26 & 385.15 & 39.26 & \\
\hline I-D-C & 40 & 40 & 40 & 39 & 40 & 39.8 & 39.8 & 405.48 & 344.12 & 374.80 & 38.21 & \\
\hline I-D-D & 39 & 40 & 41 & 41 & 40 & 40.2 & 40.2 & 412.52 & 350.88 & 381.70 & 38.91 & \\
\hline I-D-E & 40 & 41 & 41 & 41 & 40 & 40.6 & 40.6 & 419.56 & 357.64 & 388.60 & 39.61 & \\
\hline II-D-A & 42 & 43 & 42 & 41 & 42 & 42 & 42 & 444.20 & 381.30 & 412.75 & 42.07 & \\
\hline II-D-B & 43 & 44 & 43 & 42 & 43 & 43 & 43 & 461.80 & 398.20 & 430.00 & 43.83 & \\
\hline II-D-C & 41 & 42 & 42 & 43 & 41 & 41.8 & 41.8 & 440.68 & 377.92 & 409.30 & 41.72 & \\
\hline II-D-D & 42 & 40 & 40 & 40 & 41 & 40.6 & 40.6 & 419.56 & 357.64 & 388.60 & 39.61 & \\
\hline II-D-E & 43 & 43 & 42 & 44 & 42 & 42.8 & 42.8 & 458.28 & 394.82 & 426.55 & 43.48 & 42.14 \\
\hline III-L-A & 40 & 40 & 40 & 39 & 40 & 39.8 & 39.8 & 405.48 & 344.12 & 374.80 & 38.21 & \\
\hline III-L-B & 40 & 41 & 41 & 41 & 40 & 40.6 & 40.6 & 419.56 & 357.64 & 388.60 & 39.61 & \\
\hline III-L-C & 39 & 40 & 38 & 37 & 37 & 38.2 & 38.2 & 377.32 & 317.08 & 347.20 & 35.39 & \\
\hline III-L-D & 39 & 38 & 37 & 40 & 40 & 38.8 & 38.8 & 387.88 & 327.22 & 357.55 & 36.45 & \\
\hline III-L-E & 39 & 40 & 40 & 40 & 39 & 39.6 & 39.6 & 401.96 & 340.74 & 371.35 & 37.85 & 37.50 \\
\hline IV-L-A & 40 & 41 & 41 & 41 & 40 & 40.6 & 40.6 & 419.56 & 357.64 & 388.60 & 39.61 & \\
\hline IV-L-B & 39 & 39 & 39 & 38 & 39 & 38.8 & 38.8 & 387.88 & 327.22 & 357.55 & 36.45 & \\
\hline IV-L-C & 38 & 38 & 38 & 37 & 39 & 38 & 38 & 373.80 & 313.70 & 343.75 & 35.04 & \\
\hline IV-L-D & 40 & 39 & 37 & 37 & 37 & 38 & 38 & 373.80 & 313.70 & 343.75 & 35.04 & \\
\hline IV-L-E & 40 & 40 & 39 & 39 & 37 & 39 & 39 & 391.40 & 330.60 & 361.00 & 36.80 & 36.59 \\
\hline
\end{tabular}

Result found that every single shear wall has good compressive strength, beyond $30 \mathrm{MPa}$ as shown by Table 2 . However, the series I and II that were couples simple masonry wall placed at the outer side of house wall have higher compressive strength (39.54 $\mathrm{MPa}$ and $42.14 \mathrm{MPa}$ ) compared to series III and III couples simple masonry wall placed at the inner of masonry wall border edging as of $37.50 \mathrm{MPa}$ and $36.59 \mathrm{MPa}$ (Fig. 12). This phenomenon happened since the series I and II were placed under the roof and out of the sunlight. This situation has influenced the hardening of the wall that the wall compacted as it should be. It is not happened to other series, III and IV that placed outdoor and hit by sunlight. Imperfect hardening could be occurred and compactness may be reduced. Therefore, the compressive strength of III and IV series little bit lower than I and II series.

Instead of the result of Rebound Hammer Test, it is interesting that theoretical compressive strength is about the similar values of compressive strength of series III and IV. Another finding is that compressive strength of series II was higher compared to research of [13] of $40.30 \mathrm{MPa}$ as described by Fig 13. Hence, it is emphasized that the couple simple shear wall proven very good. It has higher compressive strength compared to the masonry walls without strengthening of average of $37.05 \mathrm{MPa}$ and it also has higher compressive strength compared to the theoretical compressive strength. 


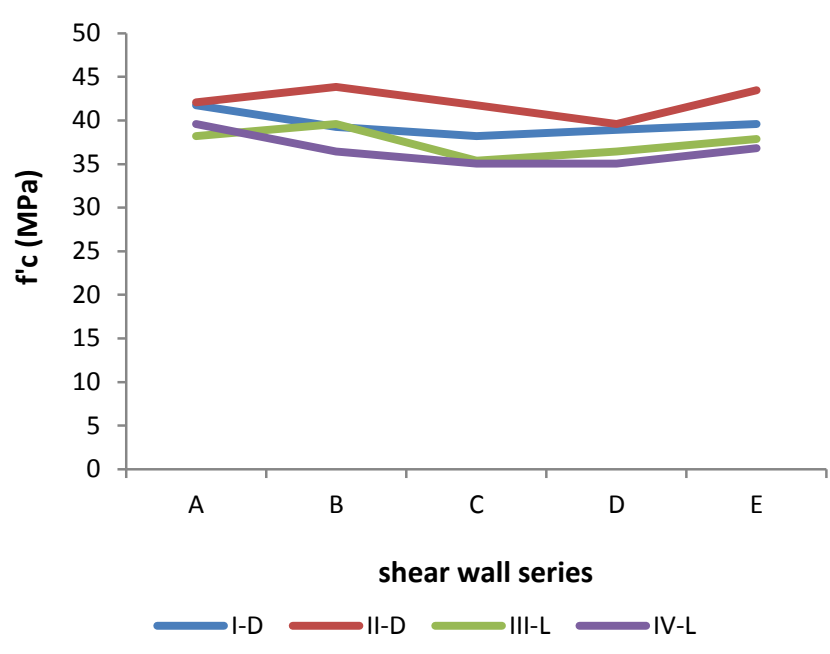

Fig 12. Compressive strength comparison of points of Rebound Hammer Test

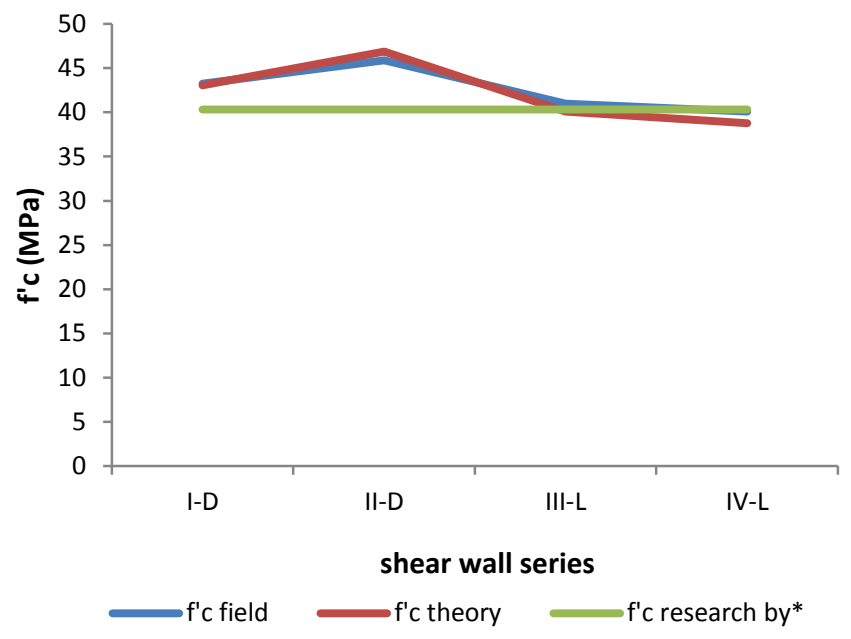

Fig 13. Compressive strength comparison among field test, theoretical, and research by [13]

\section{CONCLUSION}

The couple simple shear wall investigated in this research has proven easy to build and low-cost. The design is very simple and easy for construction and effectively strengthens the wall. It is also found that the couple simple shear wall has higher compressive strength compared to the masonry walls without strengthening and the theoretical compressive strength.

\section{ACKNOWLEDGMENT}

The authors gratefully acknowledge the support of Applied Research Grant, Ministry of Research, Technology, and Higher Education, General Directorate of Research and Development Empowerment, Directorate of Research and Service to Community, 2019-2021 period, by Contract No. 010/L6/AK/SP2H.1/ PENELITIAN/2019 for this research and publication.

\section{REFERENCES}

[1] Triantafillou, T.C., Karlos, K., Kefalou, K., Argyropoulou, E. An innovative structural and energy retrofitting system for URM walls using textile reinforced mortars combined with thermal insulation: Mechanical and fire behavior. Construction and Building Materials. 2017. 133(February). Pp. 1-13. DOI:10.1016/j.conbuildmat.2016.12.032. URL: http://dx.doi.org/10.1016/j.conbuildmat.2016.12.032.

[2] Bournas, D. Innovative Materials for Seismic and Energy Retrofitting of the Existing EU Buildings 2018. 2018. DOI:10.2760/091621. URL: https://ec.europa.eu/jrc.

[3] Li, J., Wang, Y., Lu, Z., Li, J. Experimental study and numerical simulation of a laminated reinforced concrete shear wall with a vertical seam. Applied $\begin{array}{lll}\text { Sciences } \quad \text { (Switzerland). } & \end{array}$ DOI:10.3390/app7060629.

[4] Sivaraja, S.S., Thandavamoorthy, T.S. Retrofitting of Seismically Damaged Masonry Structures Using Frp a Review. 2014. 2(01). Pp. 11-23.

[5] Boen, T., et al. Retrofitting Simple Buildings Damaged by Earthquakes. 2010.

[6] Husain, M., Eisa, A.S., Hegazy, M.M. Strengthening of reinforced concrete shear walls with openings using carbon fiber-reinforced polymers. International Journal of Advanced Structural Engineering. 2019. 11(2). Pp. 129-150. DOI:10.1007/s40091-019-0216-6. URL: https://doi.org/10.1007/s40091-019-0216-6.

[7] Ferretti, E., Pascale, G. Some of the latest active strengthening techniques for Masonry Buildings: A critical analysis. Materials. 2019. 12(7). DOI:10.3390/ma12071151.

[8] Tomaževič, M., Lutman, M. Heritage masonry buildings in urban settlements and the requirements of Eurocodes: Experience of Slovenia. International Journal of Architectural Heritage. 2007. 1(1). Pp. 108130. DOI:10.1080/15583050601126186.

[9] Suntoko, H., Iswanto, E.R., Marwanto, A., Puteraka, A.M. Design of Reinforced Concrete Shear Wall of Reactor Building, Experimental Power Reactor. Journal of Physics: Conference Series. 2019. 1198(2). DOI:10.1088/1742-6596/1198/2/022057.

[10] (13) (PDF) A REVIEW ON PERFORMANCE OF SHEAR WALL. URL: https://www.researchgate.net/publication/301324383_ A_REVIEW_ON_PERFORMANCE_OF_SHEAR_W ALL (date of application: 6.04.2020).

[11] Aragaw, L.F., Calvi, P.M. Comparing the performance of traditional shear-wall and rocking shear-wall structures designed using the direct-displacement based design approach. Bulletin of Earthquake Engineering. 2020. 18(4). Pp. 1345-1369. DOI:10.1007/s10518-01900740-y. 
[12] Gupta, R. Performance Evaluation of Various Shapes of Shear Wall using Response Spectrum Analysis. (8)2019.

[13] Susilorini, R.M.I.R., Suwarno, D., Santosa, B., Putra, L.H., Kurniawan, E. Rebound Hammer Test result of old repaired masonry wall using premixed mortar additive in tidal flooding prone area. AIP Conference Proceedings. 2018. 1977(June). Pp. 1-6. DOI:10.1063/1.5042982.

[14] Susilorini, R.M.I.R., Rejeki, V.G.S., Santosa, B., Caresta, F.D., Putro, M.S. Polymer modified mortar with bonding adhesive agent for column repairing in tidal flooding prone area. AIP Conference Proceedings. 2018. 1977(June). DOI:10.1063/1.5042969.

[15] Susilorini, R.M.I.R., Hardjasaputra, H., Sri, T., Galih, H., Reksa, W.S., Ginanjar, H., Joko, S. The advantage of natural polymer modified mortar with seaweed: Green construction material innovation for sustainable concrete. Procedia Engineering. 2014. 95(Scescm). Pp. 419-425. DOI:10.1016/j.proeng.2014.12.201.

[16] Rr. M. I. Retno Susilorini, Budi Santosa, N. Febri Satrio, R.P.B. Compressive and Splitting Tensile Strength of Polymer Modified Concrete Using Amylum and Honey. Journal of Engineering and Applied Science. 2018. 13(17). Pp. 7192-7197. DOI:http://dx.doi.org/10.3923/jeasci.2018.7192.7197.

[17] Susilorini, R.M.I.R., Santosa, B., Rejeki, V.G.S., Riangsari, M.F.D., Hananta, Y.D. The increase of compressive strength of natural polymer modified concrete with Moringa oleifera. AIP Conference Proceedings. 2017. 1818. DOI:10.1063/1.4976923.

[18] Roknuzzaman, M., Hossain, B., Mostazid, I., Haque, R. Application of Rebound Hammer Method for Estimating Compressive Strength of Bricks. Journal of Civil Engineering Research. 2017. 7(3). Pp. 99-104. DOI:10.5923/j.jce.20170703.02. 